\title{
'Becoming like us': Global discourses, local knowledge and social struggle in comparative African higher education
}

\author{
E. Weber \\ Curriculum Studies \\ Faculty of Education \\ Groenkloof Campus, University of Pretoria, \\ Pretoria, South Africa \\ e-mail: eweber@gk.up.ac.za
}

\begin{abstract}
The article critically reviews global discourses in the academic writing on comparative education dealing with the crises in African higher education. Several analyses explain how the struggling education systems can overcome obstacles and join the modern world in accordance with Western developmental models. One of the most common methodologies used to analyse comparative higher education employs the nation state as the main analytic unit. We might learn about how government policies influence reform at tertiary institutions, or how the university structure of one country compares with another; but little about the problematic impact of globalisation on the patterns observed at the national levels. Informed by writing on postcolonialism, the article proposes alternatives to the current literature: it advocates the development of critical knowledge systems and independent institutions, rooted in local societies and social struggles.
\end{abstract}

\section{INTRODUCTION}

During the 1970s a minority of black students were admitted to South Africa's historically white, liberal universities. The hidden curricula of these universities, buttressed by the structures of power located within a pale, male professoriate, rested on the idea that the Othered 'they' had to become 'like us,' at 'our' apartheid institutions. Historical precedents of political socialisation in education across the continent during the past century abound. In South Africa, prior to the formation of Union in 1910, indigenous peoples fought militarily against the dispossession of their land. The generation of black politicians that emerged - educated, anglicised, and Christianised - from the nineteenth-century mission schools sought to gain freedom by appealing to the white government and, when that failed, sending delegation after futile delegation to plead with Her Majesty's Government in Britain.

Woven into several analyses on African tertiary education is a story about how Othered, struggling education systems, each located within nation-states created by colonialism, can overcome obstacles, join the modern world, and 'become just like us'. I shall review the origins of these discourses and discuss their evolution in the 
field of comparative education, from the modernist writings of the 1960s, to the critical perspectives of the 1970s, and the contemporary work on globalisation. Writing on globalisation and postcolonialism can be used to critique the modernist solutions advocated to solve problems in African higher education, to define its goals and map paths of future development. The alternatives entail the development of critical knowledge systems and independent institutions, rooted in local societies, histories and struggles. The use of binary opposites is positive in the clarification of critique and in the formulation of political positions. But postcolonial societies and their universities and colleges were not monolithic or unchanging. Their present multiple identities were transformed irrevocably in modern times. Globalisation and postcolonialism are abstractions that can be used in the deconstruction and analysis of worldwide trends.

\section{AFRICAN HIGHER EDUCATION}

African universities and colleges have had to battle with budget cuts, declines in physical infrastructure, lecture halls that have become too small to accommodate growing numbers of students, laboratories that are not properly equipped, sporadic cuts in water and electricity supplies, faculty that have been forced to moonlight, or that have left for greener pastures. Additionally, there is poor, inefficient administrative support, libraries contain suspended journal subscriptions, outdated holdings and declining stock, teaching, learning and research function without basic equipment and supplies, and governments have frowned upon dissent. There is a huge literature that discusses these and related issues (Altbach and Teferra 2003). Problems arise when reviewing this writing: the emphasis is on description at the expense of explanation, and the implications for local knowledge production advocated or implied in how the problems chronicled, might be tackled are ignored. These issues are illustrated in the areas of access, finance, management, and governance.

\section{Access and finance}

Discussions about getting into tertiary institutions and paying for it highlight assumptions about how African universities ought to develop. In almost every country on the continent, demand for higher education is growing. Over the next ten years a minimum of 16 sub-Saharan African countries must double current enrollments to enable a constant share of their populations to pursue tertiary education. The projection ignores the massive attrition rates expected as a result of the effects of HIV/AIDS (Saint 2003, 93). This demand is often viewed as positive in the light of the contemporary global information economy. Economic pressure has produced new requirements for skilled labour, relevant research, and greater alignment with labour markets. It is argued that there is a correlation between economic growth and national income, and expanded access in tertiary education. 
Thus, 'Investments need to be targeted to fit national and regional development priorities. They also need to include major commitments to upgrade the current workforce to secure the returns on productivity that are needed to sustain longerterm investments in education, training, research, and development' (Fehnel 2003, 80). Linkages are made between economic growth, poverty, markets, and knowledge production. Growth in the market value of information and knowledge means that diverse, local knowledge will be required in the future. Institutions of higher learning can cater for this market niche. National development is viewed as taking cognisance of the relationship between poverty and market-led expansion, and hence the advocacy of greater African incorporation into the worldwide knowledge economy. Thus both the continent's own meager knowledge output can grow, and that of the rich countries as well. A World Bank paper illustrates how local knowledge can be used, Ilon argues, as part of the global drive to marketisation:

As scientists at the Institut des Sciences Agronomiques in Rwanda and at the Centro Internacional de Agricultura Tropical in Colombia learnt, local women farmers have very valuable knowledge. The two or three varieties of beans considered by the scientists to have the most potential had achieved only modest increases in yields. They then invited the women farmers to examine more than 20 bean varieties at the research stations and to take home and grow the two or three they thought most promising. They planted the new varieties using their own method of experimentation. Their selections outperformed those of the scientists by 60 to 90 percent (Quoted in Ilon 2003, 67).

However, less money and fewer resources have hitherto been available to meet the demand for higher education in Africa because of inflation, currency devaluation, structural adjustment programmes and meeting the requirements of lending organisations like the International Monetary Fund, pressures placed on government budgets to provide for people and communities affected by HIV/ AIDS, and the state subsidising students' living expenses. The relative importance of these problems vary from country to country, but generally financing tertiary education in Africa has become a headache, and the overall trend has been a decline in expenditure and the availability and quality of resources. It is sobering to learn, 'The total yearly expenditure for higher education in Africa does not even come close to the endowments of some of the richest universities in the United States. The budgets of individual universities in many industrialised countries exceed the entire national budgets for higher education in many African nations' (Teferra and Altbach 2003, 5).

Between 90-95 per cent of higher education in Africa is funded by governments. Funding from overseas donors, especially for research, has increased in recent years after a period during the 1980s and early 1990s when the Bretton Woods organisations advocated and forced governments into spending money on 
basic education because the social returns were presumed to be greater than higher education. The new funding for higher education has raised questions about whomever pays the piper calling the tune: Does it imply that funders will dictate the content and compromise the independence and integrity of research programmes? Will local and diverse intellectual capacity be built? Is there evidence that this is occurring? In at least one institution the opposite appears to be the case:

As one goes around the faculty of Medicine [University of Dar es Salaam], one wonders whether, a hundred years after Karl Peters landed here, a second partition is in progress or not. The Dental School seems to be run by the Finish, the AIDS research program by the Swedes, community health programs by the Germans, with the British, Italian, Danish all having their own corners (Hirji, quoted in Brock-Utne, 17).

There are institutions that have expanded their revenue bases and sources of income in attempts to meet the financial challenges. Their experiences are significant: they are held up as models others must emulate and they raise questions about institutional governance and the new role of the state in education reform in underdeveloped countries.

\section{Makerere University, management reform and the state}

The Ugandan and Tanzanian governments have managed to share the costs of tertiary education with students and their families. In 1992-3, 5 per cent of students at Makerere University in Uganda paid tuition; in 1999- 2000 the percentage increased to 80 per cent. What has become known as the Makerere 'miracle' was part of a set of neo-liberal reforms that turned higher education into a commodity that could be bought and sold in the marketplace. The numbers of feepaying students increased dramatically and this led to severe pressures on the available facilities. Attendance at lectures dropped because there were not enough seats, and the higher student-faculty ratios compromised academic quality. While revenue increased, its allocation within the university favoured those faculties (like humanities) that could enroll more students than other faculties (like medicine) because they were more faculty-intensive and required laboratory work. National priorities in science and technology came to play second fiddle to market prerogatives (Brock-Utne).

The changes at Makerere included reforms in curricula, management, and improvements in internal efficiency. A supportive environment that puts in place mechanisms to assist disadvantaged students, and encourages efficiency through management information and training had been emphasised. This will assist universities in tracking the effects of financial changes and improved management. - institutions are already undertaking new initiatives that include strategic 
planning, the generation of new sources of revenue, improvements in internal efficiency, a search for ways to reform curricula, and the introduction of new courses in response to labor market and social demand' (Woodhall 2003, 51).

The rise of managerialism in tertiary governance refers to the new ways in which public institutions must be controlled. It embraces the private sector ideologies and values that underpin the practices and techniques used to run universities today. These followed in the wake of the restructuring of public organisations by Western governments during the 1980s in order to make them more efficient and effective, and to improve 'performance' continuously. Efficient management informed by technical rationality is advocated under this model.

Donor aid over time has matched 'how education best fits within market development', investment in education and vested economic interests. An emphasis on tertiary management and governance followed the period of structural adjustment in Africa in order to maximise benefits flowing from market-driven growth (Ilon 2003, 63).

Greater worldwide economic integration and market expansion have resulted in changed roles for the state in education. In African countries the state has played the leading role in defining and funding research and higher education. With globalisation and the accompanying rise of information technology (IT), state control in education shifts to the market and the state's task becomes to create an environment conducive to the growth of globalisation. The following comments about IT regarding power inter-relationships with wider social structures apply equally to globalisation:

those who employ it [the information superhighway] say little about the direction and quality of its traffic, the difference activities in different lanes, who controls the lights or who gets to travel. Neither do they say much about the social and economic conditions which are helping to produce it or those which result from it. Yet it would seem that new information and communications technologies are shaping up a new economic, social and cultural order and layering new inequalities over old (Kenway 1996, 219).

The new managerialism in university governance is driven from within the state. The process produces its own contradictions: new agendas for knowledge production are set that may, as was the case at Makerere, conflict with those of the state. The African state, even if rhetorically, is still an expression of national democracy and national development. Its increasing inability to define national needs in higher education symbolises a retreat from democracy and a loss of national ownership. 


\section{COMPARATIVE EDUCATION}

Gough has critiqued the knowledge systems developed in industrialised countries. Western science is a 'specific way of thinking locally . . . one among many local knowledge systems' (Gough 2003, 54). He explains that it is common to state that we must analyse the world from different points of view, but rarely do we critique the Western knowledge systems and paradigms within which we function. 'The global reach of European imperialism gives Western science the appearance of universal truth and rationality ...' Economic globalisation produces strong pressures towards homogenisation of culture and knowledge, dominated by the science, technology, and capital of the leading industrialised nations. 'How can we think globally without enacting some form of epistemological imperialism?' (Gough 2003, 59, 63).

Eurocentrism and making sense of the world through the prism of one's own culture, views and values, have been central to the cross-cultural, comparative study of education.

Understanding one's own society was contingent upon studying the rest of the world and coming to terms with cultural, racial and national differences. This has proved to be easier said than done, despite the assistance of many minds over the course of several decades. The theoretical development of comparative education has followed that of the Western social sciences. The field has its intellectual origins in technocratic approaches of modernity, rooted in the structural functionalism that was popular in academe after World War 2. Epistemologically, there were strong links between comparative education and the social and natural sciences. The focus during the 1950s and 1960s was on positivist, modernist perspectives, scientific methodologies that would provide knowledge, based upon facts. By positivism was meant: methodologies of the social sciences should be drawn from those of the natural sciences that were seen as more advanced; there is a sameness and 'unity of method' of inquiry; a belief in generalisations and laws, and in their discovery; the relationship between theory and practice is technical; value-free study based upon facts and knowledge.

Underlying positivism was acceptance of 'the modernist faith ... in the capacity of science and technology to underpin social reform and progress, including in education, and the ability of an epistemology ... entirely bounded by the philosophy of the natural sciences to root out errors in any area of knowledge' (Welch 2003, 26-27). The evolutionary, gradualist change evidenced in Biology applied to society as well. The goal was social integration and reproduction of the status quo, not social change. Social science must be value-free and collect and present the facts, ignoring ethical and moral questions. The purpose of education was social integration and stability, 'development', and 'modernisation'. It had to train the skilled labour required for social reproduction. The job of Comparative Education was to generate the 'lessons learned' its scholars were fond of listing 
that would facilitate better policy goals, implementation, and progress. Certain positivist and functionalist assumptions were applied to poor nations in the endeavor to 'become like us'.

developing countries were always assumed to be at an early stage of progress toward the same inevitable end point: a technological, industrial, advanced bureaucratic, and pluralist society, which ... bore an uncanny resemblance to the United States or the United Kingdom . . . Modern advanced capitalist societies were always seen as . . the ultimate goal toward which the economies and politics of the former colonies of the third world must be redirected, no matter how much this disrupted traditional cultures and values (Welch 2003, 29).

The nation-state was the main analytical unit. Lessons were learned through the method of comparing the education systems of one nation(s) with other nations. The analysis of themes or problems or concepts, or paying attention to contexts and processes, were subordinated to the role of the state in comparative work. Higher education studies typically focused on the structures, functions, and developments of single countries, and it was left to the reader to make comparisons between different nations. Often comparisons were made between two countries, but beyond these they were not actually comparative. Variations among institutions were ignored or not given the attention they deserve. 'features that are different from the system/culture of the author are often highlighted, implicitly pointing the reader, usually assumed to be from the same system/culture as the author, toward the comparison to be made' (Slaughter 2001, 390). There was a preference for crunching numbers, formulating and testing hypotheses, and respect for 'reliable,' 'verifiable' quantitative work - if the statistics said it was so, then it must, objectively, be so.

Higher education in Africa can benefit from the study of locally produced knowledge through the use of life histories and oral history and methods used in cultural anthropology. This would capture the indigenous knowledges produced from below. The resultant conceptual frameworks and theories would challenge the assumptions and hegemony of the existing Western canon. The difficulty with the commonly-used methods is that they determine or are derived from the purposes of studies in higher education: descriptions of change about systems, sectors, and institutions. Contextual factors like modernisation and globalisation appear as outside influences and are not integrated with the familiar discussions about access, retention, training, faculty, finance, accountability, and leadership.

The predominant discourses within Comparative Education were questioned by ethnomethodologists who rejected positivism and structural functionalism and argued that all observations were socially constructed and there were thus different ways in which they could be analysed. During the 1970s a range of 'critical theorists,' notably the 'dependency' school associated with Andre Frank that originated in Latin America, drew on the writing of Marx to explain the role of 
education in reproducing inequality and exploitation. The 'development of underdevelopment' became the well-known symbol that described the international division of labour. This paved the way for contemporary work. A special edition of Higher Education (2001) sought to set 'critical' research agendas in the new millennium by exploring the contributions of postmodernism, feminism, political economy, and political sociology (see also Arnove and Torres 2003). The significance of the recent scholarship is twofold. First, it can be used, as we have seen, to critique the discourses applied in the analysis of problems in African higher education today. Second, in response to modernity's assumptions about the nature of scientific enquiry, the political dimensions of critique have been highlighted. For example, two leading scholars in comparative education state that although postmodernism attacked modernisation because of its refusal to accept difference, it 'textualised' and 'buried [difference] under an avalanche of recondite discursive devices'. The Other appeared in texts, detached from empirical fact and history. '[I]nstead of confronting and opposing' social oppression, 'a linguistic artifact,' cut-off from the Other's social and political reality, took its place. Preoccupied with style rather than taking a political position, 'Knowledge is divorced from commitment . . . and knowledge and meaning are devoid of ethics' (Welch 2003, 39). The end of grand, totalising narratives implies that,

we cannot define some 'master signifier', that helps us to ground, ethically and politically political action. Otherwise we cannot validate ex ante any policy recommendation in education from a theoretical standpoint, nor can we validate ex post facto the same principles for political action. The most obvious implication is the lack of a political program (Torres and Mitchell 1998, 8).

\section{EDUCATION AND POSTCOLONIALISM}

Postcolonial writing can complement the critiques of globalisation because it too does not eschew the realm of the political and in stressing historical continuity and change. Colonial subordination in Africa shifted with the granting of formal independence during the 1960s and has again been transformed under the expansion of the world market today. Postcolonial discourses foreground the social experiences and politicised identities forged in the 'former' colonies. 'attempts to appropriate the writings of the "Other" on the margin and rehabilitates their histories and perspectives on their terms, and pushes them to the centre' (Mulenga, 448). The notion of the local is therefore given specific meanings. The locus of epistemology and social science shifts from North to the South.

It follows that the view that African institutions - and scholars - must mimic intellectual identities others have imposed upon them has to be rejected. At its establishment in July 1966, President Kaunda said, 'The University of Zambia is our own university in a very real sense'. Almost four decades later the national 
pride in ownership has given way to problems about the growing gap between the role of the university and the society it supposedly serves. 'Examples of the missing link between local and university know-how can be found in most departments in all universities in Africa' (Brock-Utne, 30).

Re-connecting with the local is a contested, political process in which students have played important roles in recent times. Their organisations have connected what happens on campus with what has been occurring in the wider society. African students have protested against social injustice and their protests have had a leftist ideological orientation. Student activism has enjoyed greater social acceptance and legitimacy in Africa than compared with the West. Students have defended their group interests and have opposed attempts to reduce or do away with benefits such as stipends and subsidised housing. This has been central to critiques of the role played by international agencies in African underdevelopment and in undermining independent, national development, especially the implementation of structural adjustment programmes during the 1980s (Munene 2003). The student movements are examples of sites of political resistance at tertiary institutions, in the context of national and international issues. They are also sites for the production of new forms of local knowledge.

The struggles against apartheid and the last vestiges of colonialism in Africa in Mozambique, Guinea-Bissau, Namibia, Zimbabwe, Angola, and South Africa demonstrate the close inter-relationship between national liberation and the broader purposes of education. The following extract is from a New Year's message broadcast on January 11969 by one of Africa's outstanding intellectuals and fighters:

we started from virtually nothing. In the face of repression of the Portuguese colonialists we managed to organize and consolidate our Party and, step by step, to develop the armed struggle in Guinea, and we have now freed from colonial domination more than two thirds of our country and more than half of the population ... We are developing production, education, health facilities and trade in our liberated areas ... We have created and are creating hundreds of political, military, technical and scientific cadres. We guarantee, with complete certainty, the continuation of our struggle until final victory (Cabral 1974, 133).

The postcolonial critique that starts by emphasising local, indigenous knowledge, and national liberation raises crucial questions: What type of knowledge is privileged, how is it produced, and how can it be critiqued? Thompson discusses the problem of the relationship between social being and knowledge production. He suggests that changes in social experience determine social consciousness. The knowledge envisioned is anti-elitist and embraces the ideas forged in practice, within mass social movements:

outside the university another kind of knowledge production is going on all the time. 
I . . agree . . . it is not always rigorous . . . [but] knowledges have been and still are formed outside the academic procedures. Nor have these been, in the test of practice, negligible. They have assisted men and women to till fields, to construct elaborate social organisations, and even, to challenge effectively the conclusions of academic thought ... People starve: their survivors think in new ways about the market. People are imprisoned: in prison they meditate in new ways about the law. In the face of such general experiences old conceptual systems crumble and new problematics insist upon their presence (Thompson 1978, 8-9).

Below Machel, former president of Mozambique, describes how he turned to politics after formal education failed to alter his personal social status:

I began to understand what the key problems were, the key economic and political problems, and just why it was that we Africans were handicapped. Then 1960 taught me more - the independence of the Congo and its tumults. I began to think seriously about Mozambique becoming independent . . . Then it was that the consciousness of being oppressed, deprived, exploited, began to have its effect, as well as these ideas about independence.

At that time the Portuguese authorities were increasing their repression of all educated .. . Africans. That was something else which greatly increased our curiosity: to understand why they didn't want us to read newspapers, listen to foreign broadcasts. Yes, and then came 1961 in Angola ... (Quoted in Davidson 1972, 173).

The critical, epistemological perspectives of modernity and globalisation that developed within comparative education can be extended by analyses from below that highlight the postcolonial condition and the social struggles that have opposed it. Postcolonial writers have stressed the importance of not 'homogenising' or 'essentialising' diverse subaltern experiences and histories. Analyses of globalisation, postcolonialism, and education change ought to take cognisance of the level of abstraction at which they are situated. We have to 'keep in mind the global experience of European colonialism as a general referent whilst leaving room for the careful study of the effects in specific contexts' (Tikly, 605). The romanticisation of a pre-colonial past (or indigenous present) is implied in Nyerere's 'education for self-reliance' and postcolonial development based on Ujamaa.

Nyerere's basic premise is that certain constant patterns of human behaviours, for example, co-operation, communal sharing and unity characterized the traditional African society ... [He wished] to recreate these behaviours in postcolonial Tanzania (and Africa) ... . are these behaviours constant? Were they not affected by foreign influences ... no part of Tanzanian society was spared from colonial influence (Mulenga, 451). 
Said (1996) and Bhabha (1990) have used the concept of articulation to move beyond the boundaries of North and South and to the local to explore the interstices of 'third', cross-cultural, epistemological, historical and political spaces.

\section{CONCLUSION}

The literature on the crises in African higher education is problematic. There is the sometimes tacitly, sometimes explicitly stated assumption that the continent's universities must join the modern world following conservative, modernist paradigms within Western scholarship, and on policy terms defined by rich countries. To this end de-politicised solutions are proposed to solve the problems of access, finance, management, governance, and the acceleration of research production. Power over the Other can be exercised through the control of research, what is regarded as worth knowing and valid, and how it must be reproduced. The processes of Othering feed into hidden or open processes of silencing, repression, and the use of force. Hence the many top-down studies and the paucity of bottomup research. Local knowledge and the transformation of African higher education are political projects, inseparable from struggles for democracy and national liberation. Such projects, during the anti-apartheid period, in former Lusophone Africa, and much of the rest of the continent, must embrace social change and create new knowledges, underpinned by better values. They will support the diverse movements to African intellectual, institutional, and national independence.

The study of globalisation evolved out of discursive and political critiques about modernity within comparative education. Postcolonialism developed out of the colonial experiences of oppression and struggles for national liberation. Both fields of study revolve around the complexities of the dialectic of the local and the global. Postcolonialism has problematised the meaning of the local by stressing its diversity and hybridity, historically and during the present epoch. The academic implication is a call for more comparative empirical research, perhaps contextbound, case studies, of the modalities of change at tertiary institutions across regions and continents. Such work can explore the epistemological meanings and real-life interrelationships of the third space.

\section{REFERENCES}

Arnove, R. F. and C. A.Torres (Eds). 2003. Comparative education: The dialectic of the global and the local. 2nd edition. Rowan and Littlefield: Lanham.

Bhabha, H. K. 1990. Dissemination: Time, narrative and the margins of the modern nation. In Nation and narration, ed. H. K. Bhabha. New York: Routledge.

Brock-Utne, B. (undated). Formulating higher education policies in Africa - the pressure from external forces and the neoliberal agenda. Unpublished manuscript.

Cabral, A. 1974. Revolution in Guinea: An African people's struggle. London: Stage 1.

Davidson, B. 1972. In the eye of the storm: Angola's people. Harmondsworth: Penguin. 
Fehnel, R. 2003. Massification and future trends in African higher education. In African higher education: An international reference handbook, eds. D. Teferra and P. Altbach. Bloomington \& Indianapolis: Indiana University Press.

Gough, N. 2003. Thinking globally in environmental education: Implications for internationalising curriculum inquiry. In International handbook of curriculum research, ed. W. F. Pinar. Mahwah, N.J: Erlbaum Associates.

Higher Education. 2001. Special issue: The changing academic workplace: Comparative Perspectives (41).

Ilon, L. 2003. Foreign aid financing of higher education in Africa. In African higher education: An international reference handbook, eds. by D. Teferra and P. Altbach. Bloomington \& Indianapolis: Indiana University Press.

Kenway, J. 1996. The information superhighway and post-modernity: the social promise and the social price. Comparative Education (32) 2: 217-231.

Mulenga, D. C. 2001. Mwalimu Julius Nyerere: a critical review of his contributions to adult education and postcolonialis. International Journal of Lifelong Education (20) 6: 446-470.

Munene, I. 2003. Student activism in African higher education. In African higher education: An international reference handbook, eds. D. Teferra and P. Altbach. Bloomington \& Indianapolis: Indiana University Press.

Said, E. 1978. Orientalism. London: Routledge and Keagan Paul.

Saint, W. 2003. Tertiary distance education and technology in Sub-Saharan Africa. In African higher education: An international reference handbook, eds. by D. Teferra and P. Altbach. Bloomington \& Indianapolis: Indiana University Press.

Slaughter, S. 2001. Problems in comparative higher education: Political economy, political sociology and postmodernism. Higher Education (41): 389-412.

Teferra, D. and P. Altbach. (Eds.). 2003. African higher education: An international reference handbook. Bloomington \& Indianapolis: Indiana University Press.

Thompson, E. P. 1978. The poverty of theory and other essays. New York and London: Monthly Review.

Tikly, L. 1999. Postcolonilaism and comparative education. International Review of Education $46(5 / 6): 603-621$.

Torres, C. A. and T. R. Mitchell. 1998. Introduction. In Sociology of education: Emerging perspectives, eds. by C. A. Torres and T. R. Mitchell. Albany: State University of New York Press.

Welch, A. 2003. The triumph of technocracy or the collapse of certainty? Modernity, postmodernity, and postcolonialism in comparative education. In Comparative education: The dialectic of the global and the local, eds. R. F. Arnove and C. A. Torres. 2nd edition. Rowan and Littlefield: Lanham.

Woodhall, M. 2003. Financing and economics of higher education in Africa. In African higher education: An international reference handbook, eds. D. Teferra and P. Altbach. Bloomington $\&$ Indianapolis: Indiana University Press. 